Available online at Dakwah: Jurnal Kajian Dakwah dan Kemasyarakatan
http://journal.uinjkt.ac.id/index.php/dakwah
Dakwah: Jurnal Kajian Dakwah dan Kemasyarakatan, 23 (1), 2019, 22-39

\title{
Persuasive Strategic Communication: Tabligh in Komunitas Anak Muda Berhijrah or Hijrah Youth Community
}

\author{
Siti Sakhinah dan Armawati Arbi \\ Fidkom UIN Syarif Hidayatullah Jakarta \\ armaarbi@gmail.com
}

\begin{abstract}
The phenomenon of hijrah is becoming a trend among youth today. This study is aims to find out the persuasive communication strategies of Terang Jakarta, an Islamic youth community, to persuade youth to do hijrah through new media (social media), non-media, and their relevance to Islamic persuasive communication. This study uses qualitative research method with a descriptive approach. The results of this study are that three persuasive communication strategies can be applied both in new media and non-media. New media serves as the first gate of Tabligh, where the uses of graphics design and language are the main focus. Afterwards, non-media or face-to-face communication used as a continuation of da'wah through new media, is easier to build emotional relationships and persuasive youth here. Then, the psychodynamic strategy is the most strategies that can be applied both through new media and non-media.
\end{abstract}

Keywords: tabligh, strategy of persuasive communication, new media

\begin{abstract}
Abstrak
Fenomena hijrah menjadi tren di kalangan anak muda saat ini. Penelitian ini bertujuan mengetahui strategi komunikasi persuasif Terang Jakarta, sebuah komunitas pemuda Islam, untuk mengajak pemuda berhijrah melalui media baru, non media, dan apa relevansinya dengan komunikasi persuasif Islam. Penelitian ini menggunakan metode penelitian kualitatif dengan pendekatan deskriptif. Hasil dari penelitian ini adalah tiga strategi komunikasi persuasif dapat diterapkan baik di media baru maupun non media. Media baru (media sosial) merupakan pintu gerbang pertama Tabligh, di mana penggunaan desain grafis dan bahasa menjadi fokus utamanya. Setelah itu, komunikasi non media atau komunikasi tatap muka yang digunakan sebagai kelanjutan dakwah melalui media baru, lebih mudah untuk membangun hubungan emosional dan persuasif remaja di sini. Kemudian, strategi psikodinamik merupakan strategi yang paling banyak diterapkan baik melalui media baru maupun non media.
\end{abstract}

Kata kunci: tablibh, strategi komunikasi persuasif, media baru

Permalink/DOI: http://doi.org/10.15408/dakwahv23i1.13925

\section{Pendahuluan}

Globalisasi dan perkembangan

teknologi telah mengubah manusia

menjadi lebih dinamis terhadap pola interaksi dan komunikasi, seperti new media atau media digital untuk kepentingan transaksi informasi. Pemuda mengakses masalah agama melalui new 
media seperti blog, website, dan media sosial.

Anak-anak muda masa kini pun memanfaatkan new media sebagai sumber pengetahuan agama. Dikutip dari Republika.co.id, menurut riset dari Pusat Pengkajian Islam dan Masyarakat (PPIM) UIN Syarif Hidayatullah Jakarta yang dilakukan pada 1 September sampai 7 Oktober 2017 dengan 2.181 responden dari 34 provinsi di Indonesia, dapat diketahui bahwa anak-anak muda gemar mencari sumber pengetahuan agama melalui internet berupa blog, website dan social media dengan persentase 54,87 persen. Sumber rujukan kedua adalah buku atau kitab dengan persentase 48,57 persen. Sedangkan, channel televisi menempati posisi ketiga dengan 33,73 persen (https://www. republika.co.id/berita/dunia-islam/islamnusantara/17/11/o8/oz3o6r396-anakmuda-gemar-cari-pengetahuan-agamamelalui-internet).

Tingginya presentase pencarian sumber pengetahuan agama lewat new media dapat menjadi celah masuk bagi komunitas-komunitas anak muda Islam yang ada. Komunitas yang selama ini hanya terpaku dengan metode kajian dari masjid ke masjid bisa memanfaatkan new media untuk berdakwah. Armawati menjelaskan tiga dimensi dakwah dan komunikasi yang terjadi pada segala tingkat Komunikator, segala konteks dan semua saluran. Bila dakwah dan tabligh hanya terjadi di masjid, di podium, di pesantren saja, atau di media tertentu saja maka terlalu berat tugas para pendakwah sedangkan khalayak yang harus dijangkau berada pada wilayah yang sangat luas dan beragam (Armawati Arbi, 2003:59).Yang juga penting untuk diperhatikan, apapun media yang digunakan dalam berdakwah.

Menurut Stewart L. Tubbs dan Sylvia Moss, sebagaimana dikutip oleh Jalaludin Rakhmat dalam buku Psikologi Komunikasi, komunikasi yang efektif minimal akan menimbulkan lima hal dan salah satunya adalah pengaruh pada sikap seseorang atau bersifat persuasif (dalam Rakhmat, 1998:13). Komunikasi persuasif merupakan kegiatan penyampaian informasi kepada pihak lain dengan cara membujuk dan bertujuan untuk memengaruhi sikap emosi.

Sejalan dengan tujuan dari komunikasi persuasif, adanya komunitas anak muda Islam juga bertujuan untuk memengaruhi sikap, pendapat serta perilaku dari anak muda atau para anggotanya. Untuk mencapai tujuan tersebut, komunikasi persuasif juga sebaiknya, ditunjang melalui strategi komunikasi persuasif yang tepat.

Menurut Soleh Soemirat, dkk. dalam bukunya Komunikasi Persuasif, strategi komunikasi persuasif adalah perpaduan dari perencanaan komunikasi persuasif dengan manajemen komunikasi yang bertujuan untuk memengaruhi sikap, pendapat dan perilaku seseorang (dalam Soemirat, 2007:1.29). Menurut Melvin L. DeFleur dan Sandra J. Ball-Rokeach strategi komunikasi persuasif terbagi menjadi 3, yaitu: 1) The Psychodynamic 
Strategy, 2) The Sociocultural Strategy, dan 3) The Meaning Construction Strategy (dalam DeFleur, 1989:275).

Ketiga strategi komunikasi persuasif di atas diterapkan oleh salah satu komunitas muda Islam, yaitu Komunitas Terang Jakarta. Sesuai dengan tagline mereka "Generasi Hijrah karena Allah SWT", komunitas yang berbasis di Jakarta ini mengajak anak-anak muda berhijrah agar meninggalkan perbuatan maksiat dan tidak menoleh pada hal-hal yang menyebabkan Allah murka (dalam Azim Muhammad, 2004:67). Komunitas ini terbentuk bertolak dari alasan anak muda yang merasa segan untuk datang kajian di masjid karena memiliki tato, baru saja keluar dari rehabilitasi narkoba, dan karena belum bisa membaca Al-Quran. Pemuda yang ingin insaf tidak berani ke Masjid. Pengurus Masjid sebaiknya agar lebih terbuka dan memberi kesempatan bagi orang yang akan dan mau bertobat. Citra masjid di mata anak muda adalah tempat orang tua dan karyawan yang sudah pensiun .

Komunitas Terang Jakarta menggunakan new media seperti website, media sosial Instagram, dan aplikasi pesan Whatsapp untuk berinteraksi dengan anggotanya. Pada interaksi tatap muka komunitas ini rutin mengadakan kajian di masjid-masjid sekitar Jabodetabek, kafe, dan tempat nongkrong anak muda. Meskipun membidik anak muda usia 17-25 tahun, masih ditemukan beberapa anggota di atas usia tersebut. ${ }^{1}$ Komunitas ini menyadari perlunya metode khusus untuk mengajak anak muda berhijrah, untuk itu beberapa public figure yang juga menjalani proses hijrah sering dihadirkan dalam acara kajian, seperti Mario Irwinsyah, Teuku Wisnu, Ratu Anandita, dan Zaskia Sungkar, lewat konten-konten yang dibagikan public figure lewat media sosial baik berupa kegiatan kajian atau lewat gaya berpakaian membuat anak muda mengimitasi sehingga hijrah menjadi tren di kalangan anak muda. ${ }^{2}$

Ditemukan adanya gap antara pengurus dengan anggota, tidak semua anggota aktif berinteraksi di grup Whatsapp ataupun berkomentar di Instagram. Sampai saat ini new media pun hanya digunakan sebagai gerbang awal dakwah. Untuk memengaruhi sikap, pendapat dan perilaku anggota, interaksi pada komunikasi tatap muka secara langsung agar hasilnya lebih maksimal. Relevansi yang terjalin antara strategi komunikasi persuasif yang dilakukan oleh pengurus dengan komunikasi persuasif dalam Islam terlihat dalam berbagai aspek.

Berdasarkan latar belakang tersebut, penelitian ini layak untuk melakukan penelitian dengan judul aslinya "Strategi Komunikasi Persuasif Pengurus Komunitas Terang Jakarta dalam Mengajak Anak Muda Berhijrah”.

\section{Strategi komunikasi persuasif Melvin L. De Fleur dan Sandra J. Ball Rokeach}


Melvin L. DeFleur dan Sandra J. wilayah penerimaan seseorang, maka Ball-Rokeach, mengemukakan tiga orang tersebut akan menyesuaikan sikap strategi komunikasi persuasif (dalam DeFleur, 1989:275), adalah:

\section{The Psychodynamic strategy}

The Psychodynamic strategy atau strategi psikodinamika difokuskan pada faktor emosional atau kognitif dan tidak mengubah faktor-faktor biologis. Strategi ini didasari oleh 3 asumsi yaitu: 1) bahwa ciri-ciri biologis manusia adalah hal yang diwariskan, 2) ada sekumpulan faktor mendasar yang merupakan hasil dari belajar seperti pernyataan dan kondisi emosional, 3) terdapat sekumpulan faktor yang dipelajari untuk membentuk struktur kognitif individu. Faktor-faktor kognitif berpengaruh besar pada perilaku manusia. Jika faktor-faktor kognitif dapat diubah, maka perilaku manusia juga dapat diubah

Manusia sebagai makhluk yang suka menilai apa saja yang dilihat dan didengar, juga memberikan penilaian terhadap orang lain dan lingkungan sekitar. Dalam memberikan penilaian, seseorang memiliki wilayah penerimaan (latitude of acceptance), penolakan (latitude of rejecion), dan netral (non commitment). Diterima atau ditolaknya suatu pesan dapat dipengaruhi oleh satu variable penting yang disebut keterlibatan ego (ego involvement). Dengan kata lain ego involvement mengacu pada seberapa penting suatu isu dalam kehidupan seseorang, semakin tinggi keterlibatan ego semakin sulit dirubah pandangan dan sikapnya. Jika suatu pesan masuk ke

dengan pesan tersebut. Semakin besar perbedaan maka penerima pesan akan semakin berupaya untuk menyesuaikan sikapnya. (dalam Morissan, 2013:21-27). Dalam pendekatan melalui aspek emosional, pesan yang paling berbeda dengan penilaian dan mempunyai ego involvement yang rendah namun masuk ke wilayan penerimaan adalah pesan yang paling persuasif.

Esensi Strategi Psikodinamika adalah pesan persuasif yang efektif bersifat mampu mengubah fungsi psikologis individual dengan berbagai macam cara, sehingga mereka akan merespon seperti yang diinginkan persuader ke dalam bentuk perilaku. Strategi ini meyakini bahwa kondisi emosional seseorang adalah hasil dari belajar dan berpengaruh pada perilaku.

\section{The Sociocultural Strategy}

The sociocultural strategy atau strategi sosiokutural didasari oleh asumsi bahwa perilaku manusia dipengaruhi oleh kekuatan dari luar diri individu. Perilaku seseorang dikendalikan oleh harapan sosial yang ada dalam sistem sosial di mana kita berinteraksi dengan orang lain lebih dari kecenderungan internalnya. Setiap kelompok di mana seseorang menjadi anggota memberikan serangkaian kendali yang kuat untuk orang tersebut, seperti norma, peran yang diberikan, sistem rangking, dan menyetujui sistem kontrol sosial. 
Pendekatan sosiokultural dalam komunikasi adalah bagaimana pengertian, makna, norma, peran dan aturan yang bekerja dan saling berinteraksi dalam proses komunikasi. Suatu realitas dibangun melalui proses interaksi yang terjadi di kelompok, masyarakat dan budaya. Makna dari kata-kata dalam situasi sosial yang sesungguhnya menjadi sangat penting, juga pola-pola perilaku dan apa yang dihasilkan dari interaksi (dalam Morissan, 2014:15).

Untuk menetapkan strategi, kelompok sosial menyediakan pengertian kultur tentang perilaku yang cocok, yang melukiskan harapan-harapan dalam suatu tindakan, agar seseorang mendapatkan tempat. Kuncinya adalah pesan harus ditentukan dalam konsensus bersama. Yang juga penting untuk diperhatikan, seseorang akan termotivasi untuk bergabung ke dalam kelompok yang paling menarik atau memberikan keuntungan di mana ia menjadi anggota, dan kelompok di mana ia berasal dan berada akan menunjukkan identitas sosialnya (dalam Soemirat, 2007:8.278.28)

Strategi sosiokultur yang efektif dibutuhkan karena pesan persuasif menegaskan pada individu tentang aturan-aturan bagi pelaku sosial atau syarat-syarat kultur untuk bertindak, yang akan mengatur aktivitas. Dalam strategi ini, persuader menegaskan kepada persuade tentang aturan-aturan bagi pelaku sosial, jika pengertian telah dicapai, tugas berikutnya adalah mendefinikan kembali syarat tersebut.

\section{The Meaning Construction Strategy}

Menurut strategi ini, pengetahuan dapat memengaruhi perilaku. Strategi ini berawal dari konsep di mana hubungan pengetahuan dan perilaku dapat dicapai sejauh apa yang dapat diingat. Persuader berupaya memberikan pengetahuan mengenai sesuatu kepada orang yang dipersuasif dari lingkungan sekitar atau berita-berita yang beredar menimbulkan suatu pengertian dalam benak masyarakat bahwa hal tersebutlah yang harus diikuti, yang juga diinginkan oleh persuader.

Dalam kasus komunikasi massa, pakar komunikasi menemukan bahwa pers membentuk dan memengaruhi cara bertindak audiens terhadap isu-isu publik pada hari itu. Media "mengolah" keyakinan tentang dunia nyata dan memengaruhi perilaku, mereka mengatur makna internal dalam membentuk "agenda" topik untuk dipikirkan dan hierarki betapa pentingnya isu tersebut. Akhirnya, komunikasi massa membangun, memperluas, mensubstitusikan, dan menstabilkan makna kata-kata dalam bahasa audiens. Perubahan makna ini memengaruhi tanggapan audiens terhadap hal-hal dan masalah yang diberi label.

Dalam strategi the meaning contruction, persuader akan mema-nipulasi makna untuk memberikan pengertian yang mudah dimengerti oleh persuade dengan memberikan perumpamaan- 
perum-pamaan tanpa mengurangi arti dari pengertian itu sendiri.

\section{New Media}

New media adalah media yang kontennya terbentuk dari gabungan data, teks, suara, dan gambar yang disimpan dalam format digital dan disebarluaskan melalui jaringan berbasis kabel optik broadband, satelit dan sistem transmisi gelombang mikro (dalam Flew, 2008:2-3). Ada banyak penyebutan untuk new media, yaitu digital media, media online, media virtual, e-media, network media, media web dan cybermedia (dalam Nasrullah, 2016:13).

Menurut Lievrow dan Livingstone, ada 4 aspek yang membedakan karakteristik new media dengan old media (dalam Lievrouw, 2006:4-7), yaitu: Pertama Recombinant. New media adalah hasil kombinasi kontinyu antara teknologi yang sudah ada dengan inovasi baru, bentuk dan jenisnya terus bercabang, berekombinan dan berkembang, sedangkan old media terdiferensiasi dengan stabil menjadi beberapa bentuk atau saluran pada akhir abad ke-20.

Yang kedua adalah Networked. Pengguna pada new media saling terhubung dan dapat menjadi sender atau receiver, bahkan keduanya sekaligus, terjalin komunikasi dua arah (two way communication), dan terdesentralisasi. Sedangkan pada old media komunikasi bersifat hierarkis, satu arah (one way communication), dan tersentralisasi (one to many). Keempat, Ubiquitous. New media didesain sebagai alat personal yang menyediakan akses ke berbagai konten yang bersifat perseorangan atau layanan komunikasi, di mana pun pengguna, layanan, maupun sumber daya berada, sedangkan old media biasanya digunakan bersama-sama. Kelima Interactive. New media memberikan sarana untuk membentuk, mencari, dan berbagi konten yang selektif, dapat digunakan untuk berinteraksi dengan individu dan grup lainnya dalam skala yang lebih besar dan lebih praktis dibandingkan old media yang kurang interaktif karena tersentralisasi

Menurut Rulli Nasrullah, jenis-jenis cybermedia atau new media terbagi menjadi 11 (dalam Nasrullah, 2016:13-36), yaitu: Situs (website), yaitu halaman yang merupakan satu alamat domain yang berisi informasi, data, visual, audio, memuat aplikasi, hingga berisi tautan dari halaman web lainnya; E-mail atau dapat disebut sebagai "hybrid medium" merupakan surat elektronik yang sama seperti surat konvensional di mana ada tujuan penerima dan pengirim dan isi surat;Forum di Internet (Bulletin Board), fasilitas Mail List atau "milis" digunakan sebagai sarana komunikasi, digunakan oleh komunitas yang memiliki kesukaan atau minat yang sama atau berasal dari suatu tempat, cara kerjanya sama seperti forum; Blog, berasal dari istilah web-blog, merupakan media yang memungkinkan penggunanya untuk mengunggah aktivitas keseharian, saling mengomentari, dan 
berbagi; Wiki adalah sebuah media konten bersama, yang merupakan situs yang memuat konten hasil kolaborasi dari para penggunanya. Mirip dengan kamus atau ensiklopedi, dalam praktiknya konten-konten tersebut dikerjakan oleh pengunjung (dalam Nasrullah, 2015:46).

Selain itu, adalagi plikasi pesan melalui telepon genggam atau telepon pintar (smartphone) bisa dilihat dari cara kerja seperti BBM, Line, KakaoTalk, atau WhatsApp yang menampilkan tidak hanya pesan (percakapan) teks, tetapi juga data pesan beragam dari audio, visual, dan sebagainya. Aplikasi pesan tidak hanya menyediakan ruang untuk komunikasi dengan melibatkan hanya dua individu, tetapi fasilitasnya juga bisa melibatkan jumlah yang banyak dan terjadi di saat itu juga, selain pertukaran data dan informasi, aplikasi pesan telah sampai pada tahap interaksi audio-video seperti live streaming; Internet "Broadcasting". Internet merupakan kependekan dari interconnection networking adalah seluruh jaringan komunikasi yang saling terhubung menggunakan media elektronik yang terhubung menggunakan system global Transmission Control Protocol/Internet Protocol Suite (TCP/IP) sebagai protokol pertukaran paket untuk melayani miliaran pengguna di seluruh dunia; Peer-to-peer (P2P). Cara kerja P2P mirip seperti SMS berfungsi sebagai media berkomunikasi antar pengguna di internet, bercakap-cakap atau berkirim file. Fasilitas percakapan atau instan messaging seperti Yahoo! Messenger,
Google Talks, dan AOL. P2P juga bisa berupa perangkat berbagi file seperti Drop Box dan Google Doc.

Dan, The RSS.Content-syndication format atau RSS merupakan perangkat lunak yang berfungsi mengambil dan mengumpulkan konten berita sesuai keinginan pengguna; UDs. Multi-User Dungeons atau bisa juga disebut MultiUser Dimentions adalah suatu program komputer yang dapat diakses oleh beragam user dalam satu waktu secara bersamaan. Program ini diterapkan dalam permainan yang bisa dimainkan orang banyak disaat yang bersamaan, dimana ada yang berupa petualangan dan pertarungan; Media sosial (social media) atau social networking site seperti Facebook, Twitter, dan Skype merupakan media yang digunakan untuk mempublikasikan konten seperti profil, aktivitas, atau bahkan pendapat pengguna, juga sebagai media yang memberikan ruang bagi komunikasi dan interaksi dalam jejaring sosial di ruang siber.

\section{Level Komunikasi}

Menurut Hovlan, Jenis dan Kelley, komunikasi adalah suatu proses melalui seseorang, yaitu komunikator menyampaikan stimulus yang biasanya dalam bentuk kata-kata, dengan tujuan mengubah atau membentuk perilaku orang lain (dalam Roudhonah, 2007:21). Sedangkan menurut Onong Uchjana Effendy, komunikasi adalah proses penyampaian pesan oleh seseorang 
kepada orang lain untuk memberi tahu atau untuk mengubah sikap, pendapat, atau perilaku, baik langsung secara lisan, maupun tidak langsung melalui media (dalam Effendy, 2007:5). Dapat disimpulkan bahwa komunikasi adalah proses penyampaian pesan oleh komunikator kepada komunikan, baik secara langsung maupun tidak langsung, melalui media dengan tujuan memberikan informasi, merubah sikap, pendapat, atau perilaku.

Komunikasi dapat diklasifikasikan menjadi beberapa level atau tingkatan berdasarkan jumlah pelaku komunikasi (dalam Morissan, 2014:15), yaitu: Komunikasi Intrapersonal, yakni Komunikasi intrapersonal adalah komunikasi dengan diri sendiri, berbicara dengan diri sendiri untuk mengembangkan pemikiran dan ide-ide (dalam Vivian, 2008:450). Ada dua hal yang sangat berpengaruh dan penting dalam komunikasi intrapersonal yaitu sifat dan kognitif. Sifat menunjukkan pola yang konsisten tentang bagaimana seseorang berpikir, merasakan dan bertingkah laku dalam berbagai situasi yang dihadapi. Sifat sering digunakan untuk memprediksi tingkah laku. Dalam hal ini tingkah laku seseorang ditentukan oleh kombinasi antara sifat dengan faktor situasional pada saat itu.

Berikutnya adalah Komunikasi Interpersonal, yakni Komunikasi interpersonal pada hakikatnya adalah suatu proses, kata lain dari proses adalah sebuah transaksi dan interaksi. Transaksi mengenai gagasan, ide, pesan, simbol, atau informasi (dalam Suranto, 2011:5). Komunikasi interpersonal terkait dengan komunikasi antar orang secara tatap muka, dalam situasi yang pribadi. Bentuk khusus dari komunikasi antarpribadi adalah komunikasi diadik (dyadic communication) yang melibatkan hanya dua orang, sperti suami-isteri, dua sejawat, dua sehabat dekat, guru-murid, dan sebaginya. Ciri-ciri komunikasi diadik adalah: pihak-pihak yang berkomunikasi berada dalam jarak yang dekat; pihakpihak yang berkomunikasi mengirim dan menerima pesan secara stimultan dan spontan, baik secara verbal ataupun nonverbal.

Selanjutnya adalah kemunikasi komunikasi kelompok, Kelompok adalah sekumpulan orang yang mempunyai tujuan bersama, yaitu berinteraksi satu sama lain untuk mencapai tujuan bersama (adanya ketergantungan), mengenal satu sama lainnya, dan memandang mereka sebagai bagian dari kelompok tersebut, meskipun setiap anggota boleh jadi punya peran berbeda. Komunikasi kelompok biasanya merujuk pada komunikasi yang dilakukan kelompok kecil (small group communication), bersifat tatap muka dan umpan balik dari seorang peserta dalam komunikasi kelompok masih bisa diidentifikasi dan ditanggapi secara langsung (dalam Mulyana, 2005:83).

Dan Komunikasi Publik (public communication) adalah komunikasi antara seorang pembicara dengan sejumlah besar orang (khalayak), yang 
tidak bisa dikenali satu per satu. Contohnya pidato, ceramah, atau kuliah umum. Komunikasi publik sering juga disebut dengan istilah komunikasi kelompok besar (large group communication). Pada level komunikasi ini, kurang terdapat interaksi antara pembicara dengan pendengar, bahasa yang digunakan lebih umum supaya dapat dipahami pendengar (dalam Arni Muhammad, 2011:197). Ciri-ciri komunikasi publik adalah: terjadi di tempat umum (public), misalnya auditorium, kelas, tempat ibadah (masjid, gereja) atau tempat lainnya yang dihadiri sejumlah besar orang. Komunikasi public sering bertujuan untuk memberikan penerangan, menghibur, memberikan penghormatan, atau membujuk.

Serta komunikasi organisasi, Organisasi adalah suatu sistem kegiatan interpersonal bertujuan yang dirancang untuk mengkoordinasikan tugas individu. Perbedaan signifikan antara kelompok dengan organisasi adalah adanya birokasi pada organisasi. Komunikasi organisasi (organizational communication) terjadi dalam suatu organisasi, bersifat formal (komunikasi menurut struktur) dan juga informal (komunikasi yang tidak bergantung struktur), dan berlangsung dalam jaringan yang lebih besar daripada komunikasi kelompok. Komunikasi publik sering melibatkan komunikasi diadik, komunikasi antarpribadi, dan ada kalanya komunikasi publik.

\section{Persuasive Strategic Commu-} nication: Tabligh in Komu-nitas Anak Muda Berhijrah or Hijrah Youth Community

Karakteristik komunikasi persuasif yang ditandai dengan unsur membujuk, mengajak, mempengaruhi dan meyakinkan, jika dilihat dari perspektif Islam dapat dikategorikan pada dakwah Islam. Unsur-unsur yang terkandung dalam komunikasi persuasif menjadi dasar kegiatan dakwah karena dakwah secara etimologis berarti mengajak atau menyeru. Dakwah merupakan bagian dari tugas setiap muslim, dalam beberapa ayat Al-Quran disebutkan bahwa dakwah menuju jalan Allah SWT hukumnya wajib. Kewajiban ini didasari perintah melaksanakan dakwah disampaikan dalam bentukfiil amr, yaitu perintah secara langsung sebagaimana yang terdapat dalam surat An-Nahl ayat 125. Dakwah yang dimaksud dalam konteks yang relevan dengan komunikasi persuasif adalah dakwah billisan atau dakwah dengan menggunakan kata-kata atau lebih dikenal dengan tabligh (dalam Salam, 2011:4-5).

Surat An-Nahl ayat 125 mengandung pengertian bahwa dakwah merupakan proses berperilaku ke-Islaman yang melibatkan unsur da'i, pesan, uslub (metode), wasilah (media),

mad'u (yang didakwahi), dan tujuan. Perilaku ke-Islaman itu, dari segi bentuknya antara lain berupa irsyad, (internalisasi dan bimbingan), tabligh (transmisi dan penyebarluas- 
an), tadbir (rekayasa daya manusia), tathwir (pengembangan kehi-dupan muslim) dan aspek-aspek kultur universal. Penjelasan Al-Quran yang diturunkan melalui istin-bath (berpikir deduktif) menjadi teori utama ilmu dakwah. Adapun definisi dari ragam bentuk prilaku keIslaman yang dimaksud (Salam, 2011:5-6), yaitu : Tabligh merupakan suatu penyebarluasan ajaran Islam yang memiliki ciri- ciri tertentu. Ia bersifat massal, seremonial, bahkan kolosal. Ia terbuka bagi beragam agregat sosial dari berbagai kategori. Ini berhubungan dengan peristiwa penting dalam kehidupan manusia secara individual atau kolektif. Ia berkaitan degan sponsorship, perseorangan, keluarga, satuan jamaah atau instansi. Irsyad adalah bimbingan dan penyuluhan, yaitu proses internalisasi, transmisi, dan transformasi, ajaran Islam dalam konteks dakwah nafsiyah, fardhaiyah, dan fiahyang berasumber pada Al-Quran, Sunnah, dan ijtihad untuk mewujudkan kebenaran, keadilan dan menegakkan khittah kemanusiaan muslim dalam kenyataan kehidupan. Tathwir atau pengembangan masyarakat diidentifikasi sebagai penyebarluasan aajran Islam dalam bentuk aksi sosial. Ia merupakan satu bentuk pengorganisasian potensi sosial yang diarahkan pada sustu kondisi tertentu, dengan mengacu kepada kondisi tertentu da npada aspek-aspek yang normatifyang bersifat kondisional. Tadbir atau manajemen dakwah merupakan penataan penyebarluasan ajaran Islam dengan menggunakan prinsip dan komponen manajemen secara umum. Intinya menggerakkan berbagai komponen dalam suatu jalinan kerja sama yang diorganisasikan.

Adapun tujuan dakwah persuasif yaitu: pertama, mengubah atau menguatkan keyakinan (believe) umat terhadap syariat, dan kedua, mendorong umat untuk melakukan sesuatu sehingga dapat membentuk perilaku syar'i umat (behavior) di dalam kehidupan (dalam Uswatusolihah, 2006:4).

\section{Strategi Komunikasi Persuasif Pengurus Komunitas Terang Jakarta dalam Mengajak Anak Muda Berhijrah Melalui New Media}

a. The Psychodynamic strategy

Strategi psikodinamika melalui new media diwujudkan dengan penggunaan website, Instagram, dan Whatsapp. 1) Pada website dibagikan artikel berupa narasi hijrah, cerita dalam artikel tersebut membangkitkan faktor-faktor kognitif persuade dengan penekanan pada kesamaan pengalaman, pesan tersebut ditanamkan dalam benak persuade dan berulang kali menjadi inti dari setiap artikel yang ada. 2) Pada social media Instagram, pengurus menarik minat anak muda melalui desain, bahasa yang digunakan, dan image public figure untuk mengajak anak muda berhijrah. Upaya seperti ini sangat berpengaruh dalam mengajak anak muda datang ke kajian hingga akhirnya berhijrah, pengaruh yang ditimbulkan public figure tidak hanya 
memapar anggota komunitas tetapi juga public secara general. 3) Kemudian, chat Whatsapp yang digunakan sebagai penanganan after ummat untuk menjalin hubungan emosional dengan persuade agar interaksi komunikasi lebih mendalam.

Dalam rangkaian treatment hijrah, new media tidak menjadi platform utama pendekatan melainkan gerbang pertama dakwah. Social media digunakan sebagai tempat menggiring early judging persuade agar berpikir bahwa kajian komunitas ini ringan. Sedangkan komunikasi yang utama dan terbaiknya adalah bertatap muka langsung.

\section{b. The Sociocultural Strategy}

Setiap lingkungan memiliki serangkaian kendali berupa norma, sistem rangking, dan kontrol sosial terhadap individu yang merupakan anggotanya. Anak muda yang mengikuti akun Instagram @TerangJakarta serta bergabung ke dalam grup Whatsapp adalah anggota resmi dari Komunitas Terang Jakarta, untuk itu secara tidak langsung terdapat harapan sosial dalam sistem sosial di Instagram dan Grup Whatsapp yang mengendalikan perilaku. 1) Akun Instagram dipergunakan untuk hal-hal yang positif, pengikutnyapun memberikan timbal balik yang positif, meskipun tidak ada aturan tertulis untuk itu. Interaksi yang terjadi di Instagram pun tidak hanya terbatas pada pengurus dan pengikut di Instagram, tetapi terjadi interaksi antara sesama pelaku. 2) Berbeda dengan akun Instagram, grup
Whatsapp Terang Jakarta memiliki norma tersendiri yang sejak awal bergabung sudah dibagikan oleh admin agar diketahui dan ditaati anggota baru, juga bersifat lebih struktural karena terlihat interaksi real antara pengurus dan anggota.

Bergabungnya persuade menjadi anggota Komunitas Terang Jakarta baik sebagai pengikut di Instagram maupun anggota di grup Whatsapp menunjukkan bahwa persuade termotivasi karena tertarik dan mendapatkan keuntungan, serta mendapatkan identitas sosialnya. Karena memiliki identitas sebagai anggota Terang Jakarta, persuade menaati peraturan yang ada serta membawa diri sesuai dengan label Terang jakarta. Dalam hal ini pengurus sudah melakukan strategi sosiokultur yang efektif karena pesan sudah menegaskan pada individu tentang aturan-aturan bagi pelaku atau syaratsyarat kultur untuk bertindak, yang akan mengatur aktivitas di dalam grup Whatsapp.

\section{c. The Meaning Construction Strategy}

Pendekatan dengan strategi the meaning construction adalah dengan manipulasi makna. Implementasi strategi the meaning construction melalui new media melekat pada semua platform yang digunakan, baik itu Instagram, maupun Whatsapp. 1) Pada Instagram makna dikonstruksikan ulang melalui desain poster kajian berupa gambar dan katakata, pemaknaan ulang tersebut disesuaikan dengan gaya anak muda tanpa mengurasi arti sebenarnya. 2) Pada 
menu \#ASKTJ di grup Whatsapp. Setiap pertanyaan yang masuk dijawab dengan jawaban yang dikonstruksi ulang menggunakan bahasa yang mudah dimengerti.

Pengurus Komunitas Terang Jakarta menjalankan strategi the meaning construction dengan memanipulasi makna untuk memberikan pengertian yang mudah dimengerti oleh persuade, memberikan perumpamaanperumpamaaan tanpa mengurangi arti dari pengertian itu sendiri.

\section{a. The Psychodynamic strategy}

Strategi psikodinamik pada level komunikasi antara lain: 1) Pada level komunikasi intrapersonal, pengurus telah berkomunikasi dengan diri sendiri saat awal proses memutuskan untuk berhijrah sehingga telah berpikir, merasa, dan kemudian bertindak yaitu dengan berhijrah dan menjadi pengurus Komunitas Terang Jakarta. Sedangkan pada persuade proses ini justru menimbulkan keresahan karena terhenti pada proses berpikir. Bertemunya pengurus dengan persuade pada acara sharing session menstimulus persuade untuk merasakan karena aspek emosionalnya merespon cerita hijrah yang didengar, kemudian bertindak yaitu dengan mengikuti akun instagram, bergabung di Whatsapp dan datang ke kajian.

2) Pada komunikasi interpersonal yang terjadi saat kajian langsung, pemilihan tempat, materi, dan pemateri sangat diperhatikan. Sebagai kelanjutan dari pertemuan tatap langsung di kajian, pengurus melakukan treatment penanganan after ummat, yaitu mengambil waktu di jeda sehabis kajian. Setiap pengurus akan melayani persuade dengan one on one. Cara ini jauh lebih efektif dibandingkan saat kajian berlangsung karena persuade merasa lebih nyaman berbicara pribadi kepada pengurus. 3) Pada level komunikasi kelompok, pengurus menerapkan cara komunikasi yang ringan seperti pada acara Girls Talk. Dimana baik anggota maupun orang yang baru pertama kali datang saling mengobrol dan menceritakan pengalaman atau permasalahan yang sedang dihadapi.

4) Pada level komunikasi publik dan organisasi aspek emosional dan faktorfaktor kognitif sulit untuk diubah karena tidak adanya hubungan emosional yang dalam. Namun muncul perasaan memiliki banyak teman karena duduk bersamasama dengan orang lain. Ajakan untuk berhijrah pun lebih eksplisit karena audiens yang general.

\section{b. The Sociocultural Strategy}

Setiap lingkungan memiliki serangkaian kendali berupa norma, sistem rangking, dan kontrol sosial terhadap individu yang merupakan anggotanya. 1) Pada level intrapersonal lingkungan tempat seseorang berasal membentuk cara pikir dan perilakunya. Bagi pengurus yang pada dasarnya tumbuh dalam lingkungan keluarga yang sudah Islam, kemudian berinteraksi dengan lingkungan masyarakat, identitas sosial yang melekat 
membuat pengurus yang sudah hijrah lebih memperhatikan pembawaan diri baik dalam tampilan maupun perilaku. Dalam upaya mengajak anak muda berhijrah, persuade telah melalui proses berpikir, merasakan dan bertindak sesuai dengan lingkungan asalnya, karena belum
2. Pada level komunikasi interpersonal terjadi interaksi pada komunikasi tatap muka. Pengurus yang mempersuasif persuade menyadari adanya norma-norma dalam Islam dimana seorang wanita hendaknya menutup aurat, tetapi tidak menghakimi

Tabel Temuan Penelitian

\begin{tabular}{|c|c|c|c|}
\hline No. & Media & Strategi & Temuan \\
\hline \multirow{3}{*}{ A } & \multirow{3}{*}{$\begin{array}{l}\text { New } \\
\text { Media }\end{array}$} & $\begin{array}{l}\text { The } \\
\text { Psychodyna } \\
\text { mic Strategy }\end{array}$ & $\begin{array}{l}\text { Aspek emosional dan faktor-faktor kognitif sulit dirubah } \\
\text { karena kurangnya hubungan emosional dan kedekatan } \\
\text { antara pengurus dan persuade. }\end{array}$ \\
\hline & & $\begin{array}{l}\text { The } \\
\text { Sociocultural } \\
\text { Strategy }\end{array}$ & $\begin{array}{l}\text { Norma dan aturan pada akun Instagram karena } \\
\text { bentuknya publik, tidak dijabarkan dan tidak bisa } \\
\text { dipaksakan untuk ditaati. Namun pada grup WA norma } \\
\text { dan aturan dipaparkan secara jelas, dan dihimbau untuk } \\
\text { ditaati karena hanya pengurus dan anggota yang ada di } \\
\text { dalamnya. }\end{array}$ \\
\hline & & $\begin{array}{l}\text { The Meaning } \\
\text { Construction } \\
\text { Strategy }\end{array}$ & diterapkan melalui desain grafis dan penggunaan bahasa. \\
\hline \multirow{3}{*}{ B } & \multirow{3}{*}{$\begin{array}{l}\text { Non- } \\
\text { Media }\end{array}$} & $\begin{array}{l}\text { The } \\
\text { Psychodyna } \\
\text { mic Strategy }\end{array}$ & $\begin{array}{l}\text { Aspek emosional dan faktor-faktor kognitif mudah diubah } \\
\text { sehingga perilaku juga mudah diubah karena adanya } \\
\text { hubungan emosional dan kedekatan antara pengurus dan } \\
\text { persuade, terutama pada level komunikasi interpersonal } \\
\text { one on one. }\end{array}$ \\
\hline & & $\begin{array}{l}\text { The } \\
\text { Sociocultural } \\
\text { Strategy }\end{array}$ & $\begin{array}{l}\text { Norma dan aturan terlihat jelas pada level organisasi } \\
\text { dimana identitas sosial yang melekat mengharuskan } \\
\text { individu mampu membawa diri dan menaati norma dan } \\
\text { aturan yang berlaku dalam komunitas. }\end{array}$ \\
\hline & & $\begin{array}{l}\text { The Meaning } \\
\text { Construction } \\
\text { Strategy }\end{array}$ & $\begin{array}{l}\text { Diimplementasikan dalam setiap level komunikasi } \\
\text { terutama saat menjelaskan suatu kejadian atau menjawab } \\
\text { pertanyaan dari persuade, agar mudah dimengerti. }\end{array}$ \\
\hline $\mathrm{C}$ & $\begin{array}{l}\text { Relevansi } \\
\text { dengan } \\
\text { komunikasi } \\
\text { persuasif } \\
\text { dan Tabligh }\end{array}$ & \multicolumn{2}{|c|}{$\begin{array}{l}\text { Memiliki unsur komunikasi yang sama yaitu da'i (sender/persuader), } \\
\text { pesan (message), uslub (metode), wasilah (media), } \\
\text { mad'u (receiver/persuade), } \\
\text { sama-sama bertujuan untuk membujuk, mengajak, mempengaruhi dan } \\
\text { meyakinkan, untuk menjalankan syariat-syariat Islam. Bentuk-bentuk } \\
\text { komunikasi pada dakwah islam pun diterapkan dalam strategi komunikasi } \\
\text { persuasif pengurus seperti tabligh, irsyad, tathwir, dan Tadbir. }\end{array}$} \\
\hline
\end{tabular}

berhijrah ada disonansi kognitif yang dirasakan oleh persuade memotivasinya mencari solusi. Dan solusi itu ditemukan pada komunikasi interpersonal. persuade baik secara verbal maupun nonverbal. Norma-norma itu dijelaskan perlahan dan dalam tempo yang berkelanjutan, tidak dalam satu kali 
pertemuan, kecuali persuade mengajukan pertanyaan. Hal ini dilakukan agar persuade memiliki rasa nyaman.

3). Pada level komunikasi kelompok, pengurus mempersuasif persuade dengan cara membuat persuade merasa memiliki teman. Berkumpulnya pengurus dan persuade kemudian bertukar pikiran dengan menceritakan pengalaman hijrah masing-masing secara tidak langsung mengkondisikan persuade pada lingkungan orang-orang yang sedang berproses hijrah, bahwa hijrah dimulai dengan perbaikan diri dan amal ibadah. Jika kenyamanan dapat diperoleh maka komunikasi akan berlanjut pada level komunikasi organisasi.

4). Pada level komunikasi publik, norma dan kontrol sosial tidak secara eksplisit tergambar. Komunikasi persuasif yang dilakukan pengurus pun tidak terlalu masif karena audiens yang beragam tidak bisa dipukul rata. 5). Pada level komunikasi organisasilah norma dan kontrol sosial secara jelas terwakili dalam identitas sosial yang melekat pada pengurus dan anggota. Kewajiban menjalankan syariat Islam, aturan berpakaian, dan pembawaan diri menjadi tolak ukur individu-individu dalam organisasi. Pada tahap ini bergabungnya persuade menjadi anggota Komunitas Terang Jakarta menunjukkan bahwa persuade termotivasi karena tertarik dan mendapatkan keuntungan, serta mendapatkan identitas sosialnya. Karena memiliki identitas sebagai anggota Terang Jakarta, persuade menaati peraturan yang ada serta membawa diri sesuai dengan label Terang jakarta.

Dalam hal ini pengurus sudah melakukan strategi sosiokultur yang efektif karena pesan sudah menegaskan pada individu tentang aturan-aturan bagi pelaku atau syarat-syarat kultur untuk bertindak, yang akan mengatur aktivitas.

\section{2) The Meaning Construction Strategy}

Pendekatan dengan strategi the meaning construction dilakukan melalui manipulasi makna. Berdasarkan konteks tersebut, pengurus Komunitas Terang Jakarta berupaya memberikan pengetahuan mengenai sesuatu kepada persuade dari lingkungan sekitar atau berita-berita yang beredar, menimbulkan suatu pengertian dalam benak persuade bahwa hal tersebutlah yang harus dikuti, yang juga diinginkan oleh persuader. Pengurus komunitas Terang Jakarta mengajak anak muda berhijrah dengan menggunakan elemen-elemen yang dianggap keren dan digandrungi anak muda sehingga hal tersebut memberikan pengaruh bagi persuade. Dalam level komunikasi mulai dari intrapersonal hingga organisasi implementasi strategi the meaning construction sangat beragam, mulai dari pemahamanpemahaman tentang hijrah, muamalah, hingga fikih. Konstruksi makna dilakukan agar pesuade yang hendak atau baru berhijrah dapat memahami konteks dengan mudah. Selain itu, karena pembelajaran pokok di tiap kajian adalah membujuk anak muda untuk berhijrah, pengurus mempersuasif layaknya sebuah 
media, di mana pengurus mengolah keyakinan tentang isu yang "real" yang memengaruhi perilaku, mengatur makna internal tentang hijrah dan membentuk "agenda" topik untuk dipikirkan persuade dan memberikan hierarki betapa pentingnya isu hijrah tersebut.

\section{Strategi Komunikasi Persuasif Pengurus Komunitas Terang Jakarta dalam Mengajak Anak Muda Berhijrah Melalui Non Media (Level Komunikasi)}

Komunikasi persuasif yang dilakukan oleh pengurus relevan dengan komunikasi persuasif dalam Islam karena memiliki unsur membujuk, mengajak, mempengaruhi dan meyakinkan, untuk menjalankan syariat-syariat Islam dengan cara berhijrah. Dalam komunikasi persuasif Islam hal ini disebut sebagai dakwah Islam. Terdapat unsur da'i (sender/persuader), pesan (message), uslub (metode), wasilah (media), mad'u (receiver/persuade), dan tujuan. Bentuk-bentuk komunikasi persuasifnya antara lain: a) Tabligh (transmisi dan penyebarluasan) sesuai dengan pengemasan konten yang dilakukan pengurus dengan menggunakan new media dan nonmedia pesan mampu menjangkau persuade dimanapun dan kapanpun tanpa batasan kriteria. b) Irsyad, (internalisasi dan bimbingan) sama halnya dengan treatment one on one atau penanganan after ummat dimana interaksi yang terjadi lebih mendalam dan menimbulkan kedekatan, serta memberi efek pada aspek-aspek emosional dan faktor-faktor kognitif.

Tathwir (pengembangan kehidupan muslim) diimplementasikan dalam aksi sosial pengurus yaitu mengajak anak muda yang berhijrah mengikuti beberapa program sosial antara lain sedekah jumat, patungan bermanfaat, dan daily food bank Ramadhan. d)Tadbir (rekayasa daya manusia) pengurus menjalin kerja sama banyak komunitas lain untuk menunjang proses hijrah persuade salah satunya kerja sma dengan komunitas Malarosa untuk pembelajaran tahsin.

\section{Kesimpulan}

Berdasarkan hasil penelitian yang dilakukan melalui wawancara, observasi, dan dokumentasi, maka dapat disimpulkan beberapa hal sebagai berikut: 1. Strategi komunikasi persuasif pengurus komunitas Terang Jakarta dalam mengajak anak muda berhijrah melalui new media antara lain,

Strategi psikodinamika dengan artikel cerita hijrah pada website, desain, bahasa, dan image public figure pada Instagram, serta penanganan after ummat pada chat Whatsapp. Strategi sosiokultural melalui aturan atau norma tidak dipaparkan secara langsung di Instagram tapi disadari sendiri oleh followers, sedangkan pada grup Whatsapp aturan dipaparkan secara formal agar diketahui oleh setiap anggota. Strategi the meaning construction melalui new media melekat pada semua platform yang 
digunakan, baik itu Instagram, maupun Whatsapp dengan memberikan pengertian yang mudah dimengerti oleh persuade tanpa mengurangi arti dari pengertian itu sendiri.

2. Strategi komunikasi persuasif pengurus komunitas Terang Jakarta dalam mengajak anak muda berhijrah melalui nonmedia antara lain, Strategi psikodinamika adalah dengan pendekatan aspek emosional melalui sharing session, komunikasi persuasif yang paling efektif terjadi di level komunikasi interpersonal one on one, kedekatan yang terjalin mempermudah proses hijrah persuade. Strategi sosiokultural dengan pemaparan aturan atau norma hasilnya lebih maksimal pada level komunikasi organisasi karena indentitas sosial yang melekat pada pengurus maupun anggota mengubah perilaku persuade.Strategi the meaning construction diimplementasikan pada level komunikasi mulai dari intrapersonal hingga organisasi dengan sangat beragam, mulai dari penyampaian materi kajian hingga menjawab pertanyaan persuade dengan bahasa yang mudah dimengerti anak muda tanpa mengurangi arti.

3. Relevansi strategi komunikasi persuasif pengurus komunitas Terang Jakarta dalam mengajak anak muda berhijrah dengan komunikasi persuasif dalam islam ada pada unsur dan karakteristik komunikasinya dimana terdapat da’i (sender/persuader), pesan (message), uslub (metode), wasilah (media), mad'u (receiver/persu-de), dan bertujuan membujuk, mengajak, mempengaruhi dan meyakinkan, untuk menjalankan syariat-syariat Islam. Bentuk-bentuk komunikasi pada dakwah islam pun diterapkan dalam strategi komunikasi persuasif pengurus seperti tabligh, irsyad, tathwir, dan Tadbir.

\section{Saran}

Berdasarkan pengamatan secara langsung, maka beberapa saran yang peneliti sampaikan kepada pengurus komunitas Terang Jakarta antara lain: Pengurus komunitas Terang Jakarta perlu meningkatkan keaktifan respon admin Instagram dan Whatsapp, karena melalui pengamatan beberapa pertanyaan di kolom komentar Instagram tidak mendapatkan respon dari admin, sedangkan pada grup Whatsapp respon pengurus dalam menjawab pertanyaan terlalu lama, bahkan beberapa pertanyaan tidak terjawab dan tertutup oleh informasi lain; Pengurus perlu mengaktifkan kembali website resmi Terang Jakarta agar lebih up to date, karena posting-an terakhir di website pada tahun 2017. Menu \#hijrahku berpeluang besar menarik minat anak muda untuk berhijrah lewat cerita dan pengalaman yang orang lain bagikan; Pengurus perlu mengintensifkan kegiatan seperti Girls Talk dan Boys Talk karena kegiatan dengan pengemasan sharing session ini 
lebih banyak peminat dan lebih efektif mengajak anak muda berhijrah.

\section{Daftar Pustaka}

Arbi, Armawati . 2003. Dakwah dan Komunikasi. Tangerang: UIN Jakarta Press.

DeFleur, L Melvin, and Sandra J Ball Rokeach. 1989. Theories of Mass Communication 5th Edition. New York: Longman.

Effendy, Onong Uchjana . 2007. Ilmu, Teori dan Filsafat Komunikasi. Bandung: Citra Aditya Bakti.

Flew, Terry. 2008. New Media: An Introduction (3rd Edition). South Melbourne: Oxford University Press.

Lievrouw, Leah, and Sonia Livingstone. 2006. Handbook of New Media: Social Shaping and Social Consequences of ICTS. London: Sage Publications Ltd.

Moloeng, Lexy J. 2005. Metode Penulisan Kualitatif. Bandung: PT Rosda Karya.
Morissan. 2013. Psikologi Komunikasi.

Bogor: Penerbit Ghalia Indonesia.

-. 2014. Teori Komunikasi Individu hingga Massa. Jakarta: Kencana Prenadamedia Group.

Muhammad, Ahmad Abdul Azhim. 2004. Strategi Hijrah: Prinsip-prinsip dan Ilmiah Tuhan. Solo: Tiga Serangkai.

Muhammad, Arni. 2011. Komunikasi Organisasi. Jakarta: Bumi Aksara.

Mulyana, Deddy. 2005. Ilmu Komunikasi: Suatu Pengantar. Bandung: Remaja Rosdakarya.

Nasrullah, Rulli. 2015. Media Sosial: Perspektif Komunikasi, Budaya, dan Sosioteknologi. Bandung: Simbiosa Rekatama Media.

-. 2016. Teori dan Riset Media Siber (Cybermedia). Jakarta: Prenada Media Group.

Pawito. 2007. Penelitian Komunikasi Kualitatif. Yogyakarta: Pelangi Aksara Yogyakarta.

Rakhmat, Jalaludin. 1998. Psikologi Komunikasi. Bandung: Rosdakarya.

Roudhonah. 2007. Ilmu Komunikasi. Jakarta: UIN Jakarta Pers.

Salam, Agus. 2011. "Telaah Persuasif Alquran." Jurnal Universitas Pendidikan Indonesia 4-6. 
Soemirat, Soleh, Hidayat Satari, and Asep

Suryana. 2007. Komunikasi

Persuasif. Jakarta: Universitas

Terbuka.

Suranto, Aw. 2011. Komunikasi

Interpersonal. Yogyakarta: Graha

Ilmu.

Uswatusolihah, Uus. 2006. "Dakwah dengan Pendekatan Komunikasi Persuasif." Jurnal Ibta' Vol.4 No.1 Januari-Juni 4.

Vivian, John. 2008. Teori Komunikasi

Massa. Jakarta: Prenada Media Group.

Yulianto, Agus. 2018. Anak Muda Gemar Cari Pengetahuan Agama Melalui Internet. Juli 15. https://www.republika.co.id/berita /dunia-islam/islamnusantara/17/11/o8/oz3o6r396anak-muda-gemar-caripengetahuan-agama-melaluiinternet.

Catatan Akhir

${ }^{1}$ Hasil Observasi media dan non media pada 1 Maret 2018, di Instagram dan Masjid Raya Pondok Indah.

${ }^{2}$ Hasil Observasi non media pada 11 Maret 2018 di Masjid Mall Bintaro Jaya Xchange. 